\title{
EFFECT OF FLUID THERAPY ON BODY WATER CONTENT IN PATIENTS UNDERGOING ELECTIVE ORTHOPAEDIC SURGERY
}

Paulina Iwaniuk ${ }^{1}$, Hubert Kolano ${ }^{2}$, Dorota Siwicka-Gieroba ${ }^{1}, Z^{2}$ iemowit Rzecki ${ }^{1}$, Edyta Wilczyńska ${ }^{1}$, Małgorzata Barud ${ }^{1}$, Jacek Gągała ${ }^{3}$, Wojciech Dąbrowski ${ }^{1}$

1. Department of Anaesthesiology and Intensive Therapy Medical University of Lublin, Poland,

2. Regional Hospital in Nisko, Poland,

3. Department of Orthopaedic and Traumatology Medical University of Lublin, Poland.

\section{INTRODUCTION}

Fluid therapy is frequently used in order to correct perioperative haemodynamic disorders in patients undergoing surgery under spinal anaesthesia. Unfortunately, an inappropriate fluid administration may result in tissue edema leading to severe postoperative complications.

"Water is a friendly element to whomever is familiar with it and knows how to treat it." Johann Wolfgang von Goethe

\section{THE AIM}

The aim of this study was to compare the effect of perioperative crystalloids infusion vs. gelatine infusion on body water content in orthopaedic patients.

\section{METHODS}

Adult patients undergoing elective knee arthroplasty surgery under spinal anaesthesia were enrolled.

All fluids were administered at the dose $10-15 \mathrm{~mL} / \mathrm{kg} / \mathrm{h}$ during surgery.

\section{Exlusions:}

- ASA III

- Severe lung, heart and CNS diseases

- Chronic kidney disease

- Amputation of the limb

- Massive fluid resuscitation following perioperative bleeding

- Complicated periopertive period
Patients were divided into four groups:

$\mathrm{R}$ - patients receiving Ringer solution

P - Plasmalyte $\mathbb{R}$

S - Sterofundin ${ }^{\circledR}$ ISO

$\mathrm{G}-$ Gelaspan $\AA$.

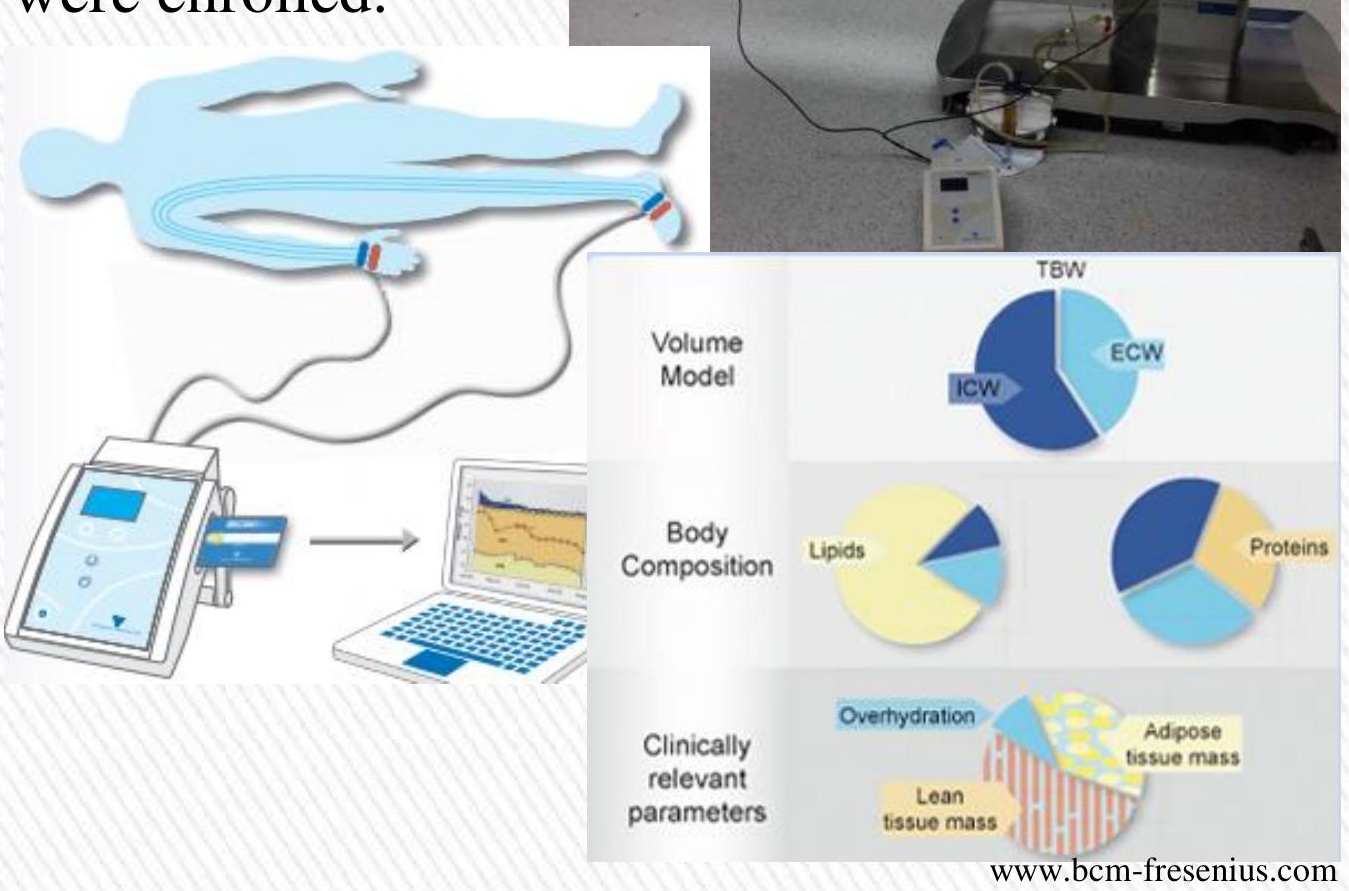

The body water content was assesed by volume excess (VE), total body water (TBW), extracellular body water (ECW) and intracellular body water (ICW) by whole body bioimpedance at 5 time - points.

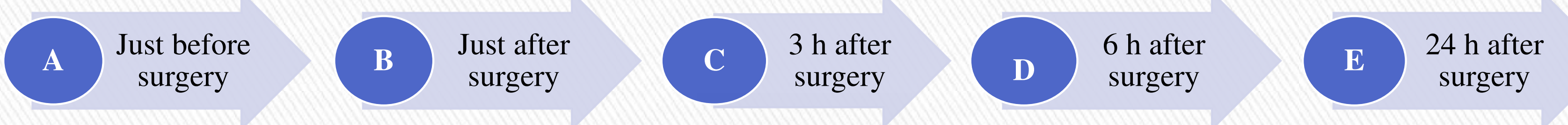

\section{RESULTS}

75 patients (27 female and 48 male) aged $34-84$ were studied.

1. VE increased in group $R, P$ and $S$ at time points $B(p<0.05), C(p<0.01)$,

$\mathrm{D}(\mathrm{p}<0.01)$ and $\mathrm{E}(\mathrm{p}<0.01)$.

2. ECW increased in groups $R$ and $S$ at time points $\mathrm{B}, \mathrm{C}, \mathrm{D}$ and $\mathrm{E}(\mathrm{p}<0.001)$.

3. ECW increased in group $P$ at time points $\mathrm{B}$ and $\mathrm{C}$, and decreased at time points D and E (Fig. 1).

4. Gelatine infusion did not affect VE, TBW, ECW and ICW.

5. There were significant differences in VE between group $R$ and $G$ at time points $\mathrm{C}$ and $\mathrm{E}$ and between group $\mathrm{P}$ and $\mathrm{G}$ at time points $\mathrm{C}, \mathrm{D}$ and $\mathrm{E}$ (Table 1).

6. TBW and ICW were significantly higher in group $\mathrm{R}$ than $\mathrm{G}$ at time point $\mathrm{C}$ $(\mathrm{p}<0.05)$.

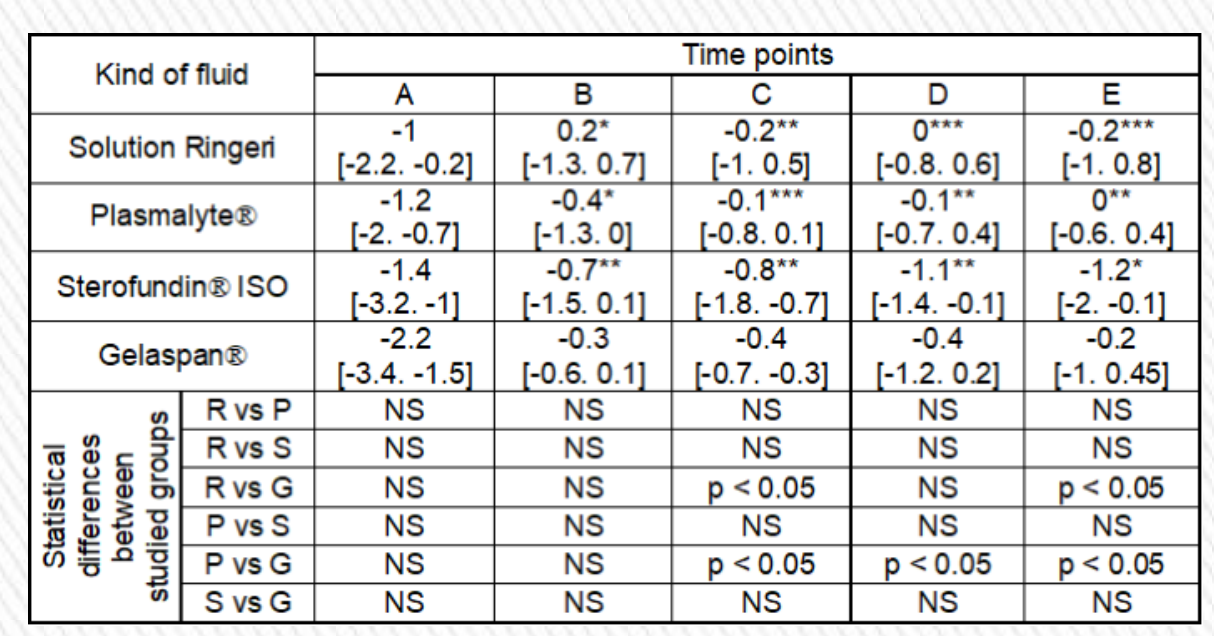

Table 1. Changes in volume excess (VE $(\mathrm{L}))$ in patients receiving solution Ringeri (R), Plasmalyte ${ }^{\circledR}(P)$, Sterofundin ${ }^{\circledR}$ ISO $(S)$ and Gelaspan $®(G)$. $* \mathrm{p}<0.05, * * \mathrm{p}<0.01, * * * \mathrm{p}<0.001-$ differences between baseline value (before
fluid resuscitation - A) and volume excess just after surgery (B) and 3,6 and 24 hours after surgery (C, D and E, respectively).

\section{CONCLUSIONS}

1. Perioperative crystalloids infusion increases total body water, particularly in extravascular space.

2. Use of gelatine does not affect body water homeostasis and seems to be safe in patients undergoing elective orthopaedic surgery under spinal anaesthesia. 